\title{
Web of Concepts Critical to Today's World Epistemological Beliefs Cognitive Flexibility and Balance
}

\author{
Marlene Schommer Aikins* \\ Department of Counseling, Educational and School Psychology, Wichita State University, USA
}

Submission: November 11,2017; Published: December 01, 2017

*Corresponding author: Marlene Schommer Aikins, Department of Counseling, Educational and School Psychology, Wichita State University, USA, Email: Marlene.Schommer-Aikins@wichita.edu

\section{Introduction}

Although there are many cognitive and affective variables critical to the world today, I would like to focus on web of three major concepts that seem particularly pertinent today. These major concepts are epistemological beliefs (beliefs about the nature of knowledge and learning), cognitive flexibility (adapting thinking in response to situational demands, and balance (regulating thinking by using the full spectrum of epistemological a beliefs and cognitive flexibility). When viewed as web, they function in a complex, integrated symphony to help individuals regulate their thinking and actions in an ever changing world. William Perry [1] studied beliefs about the nature of knowledge and learning in the late 1950s. Their influences remain important in the world today.

We live in a world in which fact, fiction, reflection, and careless speech can travel through cyberspace in a split second to anyone in the world who is digitally connected. Any falsehood, any bully comment, and any fake news can destroy careers, confuse voters, mislead decisions, or lead to suicide. How do we arm ourselves with the psychological, cognitive, and emotional armor to discern what information should be considered or believed; and what information that should be disputed or ignored? And when does information become knowledge? Epistemological beliefs can contribute to our armor. For example, some of these beliefs include: beliefs about the certainty of knowledge (ranging from absolute versus evolving), the source of knowledge (ranging from simple observation or handed by authority to multi-sourced), and the structure of knowledge (ranging from an unorganized accumulation of facts to or an integrated well-structured or illstructured configuration) [2].

At the most basic level, many researchers would propose that the inundation of information from sources of varying levels of credibility needs to be filtered through the beliefs that knowledge comes from multiple sources (and cross-checked), highly integrated, and assumed to be evolving in nature [3]. However, this proposition is inadequate in itself. So we build our hypothetical web with a second factor that is critical to the application of epistemological beliefs in the process on acquiring and applying knowledge, namely cognitive flexibility. Cognitive flexibility has been defined as the propensity to change one's thinking and problem solving when faced with situational demands. The key components of cognitive flexibility and the epistemological belief that supports that component include: (a) being vigilant to sense a need for change- supported by belief in evolving knowledge; (b) engaging in change -supported by belief in complex knowledge; (c) monitoring the appropriateness of change -- supported by belief in multi-sources and cross validation; (d) continuing vigilance to update changes supported by belief in evolving knowledge [3,4]. Cognitive flexibility is critical in a world that is changing, in a society that is diverse, and in a digital world that rapidly raises our awareness of new and diverse global cognition.

The third factor to consider in the web of essential concepts is balance. It is not assumed that beliefs that knowledge is complex, evolving, and multi-sourced are the only form of situation-appropriate thinking. There are times when simple, expeditious conclusions serve us best (a car is about to hit you, get out of the way). There are times when resisting change helps us avoid the whiplash of in decisiveness (inability to make a decision) [3]. The most elusive factor then is the balance of cognitive flexibility and aspect of epistemological beliefs. Researchers [5,6] have clearly called for a more reasoned view of cognitive flexibility. They asserted that to assume certain adaptive strategies are appropriate for all situations is a fallacy. What is really needed is flexibility that is regulated by situational demands. Although balance may be illusive, cognitive flexibility 
may be uncomfortable, and epistemological beliefs may be illdefined, they nevertheless are critical in our fast-paced global society. Virtually all fields of expertise can benefit from deeper understanding of this web of concepts. It only remains for many of us to work collaboratively (and perhaps competitively) to investigate and understand the inner workings of this web.

\section{References}

1. Perry WG (1968) Patterns of development in thought and values of students in a liberal arts college: A validation of a scheme Final Report. Bureau of Study Counsel Cambridge, USA.

2. Schommer Aikins M (2004) Explaining the epistemological belief system: Introducing embedded systemic model and coordinated research approach. Educational Psychologist 39(1): 19-29.
3. Schommer Aikins M (2011) Spontaneous cognitive flexibility links to epistemological beliefs. In J Elen, E Stahl, G Clarebout, R Broom (Eds.) Links between Beliefs and Cognitive Flexibility. New York, USA, pp. 6177.

4. Schommer Aikins M, Easter MK (2016) Epistemic beliefs and cognitive flexibility among students from emerging markets Proceedings of the American Society of Business and Behavioral Sciences $23^{\text {rd }}$ Annual Conference. USA.

5. Bonanno GA, Burton CL (2013) Regulatory flexibility: An individual differences perspective on coping with emotion regulation. Perspectives on Psychological Science 8(6): 591-612.

6. Cheng C, Chiu C, Hong Y, Cheung JS (2001) Discriminative facility and its role in the perceived quality of interactional experiences. Journal of Personality 69(5): 765-786.

Your next submission with Juniper Publishers will reach you the below assets

- Quality Editorial service

- Swift Peer Review

- Reprints availability

- E-prints Service

- Manuscript Podcast for convenient understanding

- Global attainment for your research

- Manuscript accessibility in different formats

( Pdf, E-pub, Full Text, Audio)

- Unceasing customer service

Track the below URL for one-step submission https://juniperpublishers.com/online-submission.php 